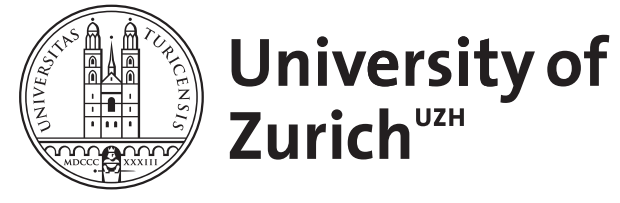

Zurich Open Repository and Archive

University of Zurich

University Library

Strickhofstrasse 39

CH-8057 Zurich

www.zora.uzh.ch

Year: 2014

\title{
Farmers and Their Environment: Protective Influences of the Farming Environment against the Development of Allergies
}

\author{
Gassner, Markus
}

DOI: https://doi.org/10.1159/000359961

Posted at the Zurich Open Repository and Archive, University of Zurich ZORA URL: https://doi.org/10.5167/uzh-98047

Journal Article

Published Version

Originally published at:

Gassner, Markus (2014). Farmers and Their Environment: Protective Influences of the Farming Environment against the Development of Allergies. Chemical Immunology and Allergy, 100:278-286.

DOI: https://doi.org/10.1159/000359961 


\title{
Farmers and Their Environment: Protective Influences of the Farming Environment against the Development of Allergies
}

\author{
Markus Gassner \\ Institute of Allergology and Dermatology and Institute for Family Medicine, University of Zurich, \\ Zurich, Switzerland
}

\section{(C) Free Author Copy - for personal use only}

ANY DISTRIBUTION OF THIS ARTICLE WITHOUT WRITTEN CONSENT FROM S. KARGER AG, BASEL IS A VIOLATION OF THE COPYRIGHT.

Written permission to distribute the PDF will be granted against payment of a permission fee, which is based on the number of accesses required. Please contact permission@karger.ch

\begin{abstract}
Compared with other population groups, the way of life of farmers can be viewed as being similar to that of our ancestors. The settled continuation of generations within certain critical geographical and environmental conditions requires a special local network of knowledge and experience. The immune system provides protection against microbes and their toxins. Each strong reaction impedes an active adaptation. Allergy is therefore a harmful intolerance and represents one of many different paradoxes. The aim of this chapter is to demonstrate some of the interactions of tolerance and adaptation from a historical background.
\end{abstract}

(c) 2014 S. Karger AG, Basel

\section{Farmers and Their Environment}

Nature gives a certain time period to each living organism. The length of life depends on the genes and the environmental factors on the era and geographic site of where and when organisms are living. These very trivial aspects of dependence on time and place are crucial if we want to understand the influ- ence of social and hygiene conditions in the history of medicine. This has been true for the past and will be for the future. As the future is unknown, it might be worthwhile comparing present differing living conditions in societies and countries, and comparing them with the situations of our predecessors (fig. 1).

\section{Agriculture, the Art of Adaptation}

In early history, when agriculture developed, it was an art aimed at achieving an optimal local adaptation, to reduce the need for migration by producing more food or wood for buildings and energy, as well as fibers for clothes. Agriculture led to the development of adaptation technologies in different areas. Tolerance of local conditions instead of migration is the first partial aspect of an active adaptation for long-term survival. It is only possible to harvest what grows under the climatic and geographic conditions. Human beings used seeds from grasses which were selected and bred into diverse cereal species in order to render better harvests of less perishable grains. By good care of plants and animals - ac- 


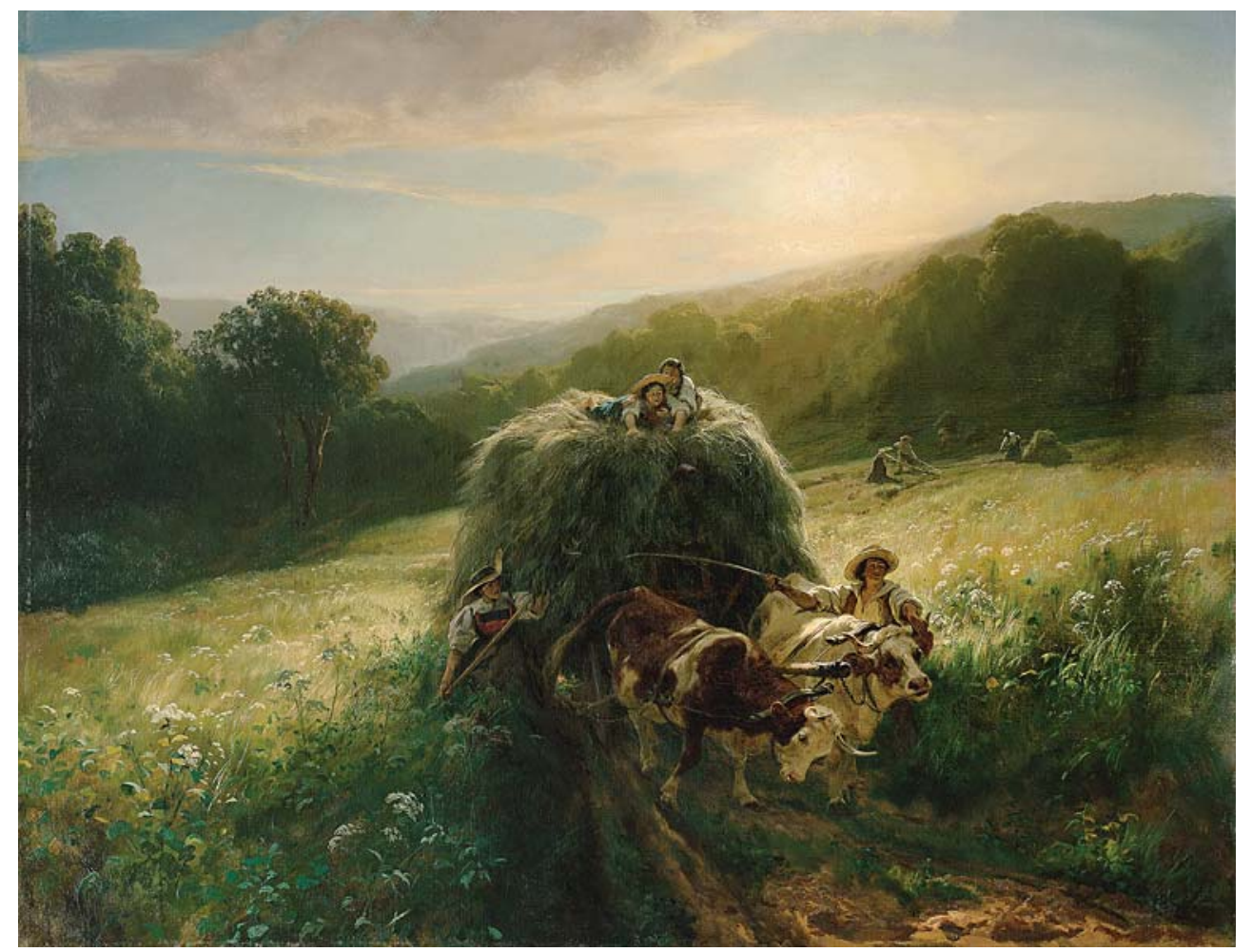

Fig. 1. The 'Heuwagen' by Rudolf Koller (1826-1906) shows many aspects of historical cross-linked situations in the agriculture of Switzerland: co-working of many family members, rapid harvesting before a thunder storm by knowledge of local meteorological conditions, use of cows (horses) for food (milk, meat, leather, etc.) and transportation with 'the archaic biodiesel' as food energy. Grass and cereals were the only primary energy for all local overland transportation and represented a significant competition to the production of every food for humans as well all farm animals.

tive adaptation - survival is possible for more human beings and animals under otherwise intolerable life conditions.

In central Europe, especially in mountainous areas, the change of seasons was the primary specific difficulty for survival. Harvest time was limited to summer and early autumn. Survival in winter was impossible without the preservation of food. The best harvest is useless when the fruits cannot be eaten at the right time. Conservation of food was one of the first conditions determining that more people could live in the same area. The property of more and better food gave and gives rise to envy and greed among human beings and can be the reason for robbery, social conflicts and wars.
In this medical-historic article, we cannot comment on the effects of agricultural products on consumers, or on the economic conditions regarding the distribution of goods, i.e. politics. However, with regard to public health the prophylaxis in the production of food is crucial: one aspect here is occupational diseases in farmers. The following pages will focus upon the effects of 'battles' between farmers and microorganisms with immunologic 'weapons'. The technologies of preservation (drying and packing) were of immense importance for our ancestors as well as their domestic animals prior to the efficient use of altered temperature (boiling and freezing). This was especially crucial for human beings who not only had to adapt their own life, but also the life of the domestic animals to the seasonal climatic conditions. 


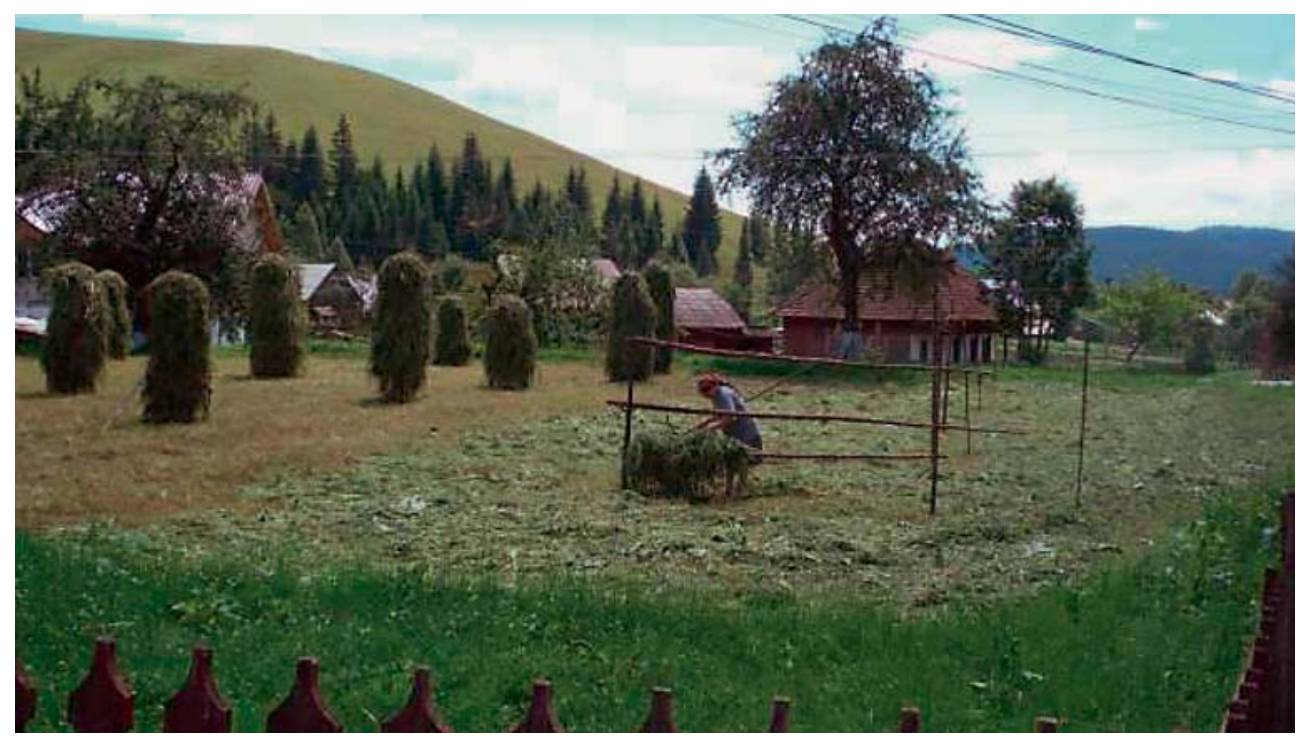

Fig. 2. Drying hay needs long blades of grass. That is why grass could only be cut once to thrice a year in mountain areas. The photo shows two archaic techniques still used in 2009 on a farm in Romania. The same techniques were commonly used in Switzerland in the last century, now replaced by different kinds of silage techniques [2], which allows the grass to be cut up to six times every year in some places, and for some grasses to be cut before they are flowering and release there allergenic pollen!

\section{Drying}

The life of microorganisms is impaired by a reduction of water content, which can be used for preservation. This mechanism was used for the preservation of cereals and grasses as basic food, and also as feed for domestic animals in winter (hay). Ramazzi$\mathrm{ni}$, the father of occupational medicine, reported on an illustrative example of this technology, the disease of the sifters of cereals:

Almost all persons who earned their bread by sieving and measuring cereals, are short-winded, cachectic and rarely reach a great age. [1]

We do not know whether this 'fever' of the grain sifters was asthma according to modern medicine, organic dust toxic syndrome via endotoxins and glucans, or chronic obstructive pulmonary disease (COPD). In those times farmers did not have cigarettes!

The harvesting of hay requires exact knowledge of meteorology. Grass and cereals had to be cut at an optimal point of time and dried rapidly in order to be preserved. When the soil was too wet, the cut grass would rot. Grass could be dried either by hanging it on poles or long stalks (fig. 2), which was time consuming and energy sapping. Moist hay in the stable was a catastrophe. The fermentation process caused heat, sometimes self-inflammation and fires, and in former times many stables burnt down. Fermentation via thermophilic spores spoilt the hay even for animals and caused severe diseases in cattle and farmers, such as pneumoconioses (farmer's lung). Meadows in shadowy areas presented more problems in the production of less dangerous hay.

\section{Wrapping}

Most microorganisms need oxygen for survival. Liquids could be preserved via fermentation in closed vessels, as for instance wine or must. Partly, this was also possible for solid foods (e.g. sauerkraut). The preservation of milk in the form of cheese in different variations is one of the ancient and highly developed arts of agriculture. The bark of the cheese was the wrapping material. 
A milestone in agriculture was the discovery of the technique of silage by Virtanen [2]. This technique not only prevented rotting and improved the nutritional qualities compared to dried hay, but also allowed an earlier and more frequent cutting of the grass. Consequently, most grasses could then be cut prior to blooming. Therefore, it might be possible that pollen emission and also immission was then reduced. It remains uncertain which grasses might be less or more affected by the lack of seeding. Therefore, it is unclear what influence this technique has on the immission of allergenic molecules from grass pollen in different regional conditions.

\section{Mechanical Technology}

The tractor with a gasoline motor can be regarded as a symbol of the development of modern technology, replacing domestic animals like horses and oxen in the production (ploughing) and transport of foods. Tractors, trucks and railway engines replaced classical transportation by horses. Horse breeding for this purpose became obsolete. The whole transport business in the countryside became 'dismicrobiologized'. Zoonotic epidemic infectious diseases were no longer a problem for the transport of goods. Coal and oil allowed the production of engines and railways, leading to a gigantic outsourcing of agriculture. The same technology also opened up new vast and very fertile areas used for agriculture by corrective measures applied to the water supplies from mountains and river plains down to the sea. Concerning the supply of energy, coal made the cities independent from woods and forests. For this reason, forests disappeared as a result of cultivation, while others recovered or were endangered by air pollutants of fossil fuels. Cities, however, could grow 'infinitely', thereby causing the exponential growth of the population on Earth.

There is a certain irony in this story: the energy consumption of mankind is setting new limits, both geographically and biologically. Agriculture today is abused worldwide in order to produce 'biological fuels' instead of foods. In former times, it was politically essential who the owner of land or a territory was. Wars were started during the last millennia in order to keep or gain the productivity of farmers. Today, values in the globalized, economized and commercialized world have changed. As a consequence, health has also been affected. The epidemiologic rise of allergy seems to be an indicator of this development.

\section{Allergology}

Our immune system evolved in order to defend the organism against microbial dangers. In this endeavor, compromises and adaptation processes are necessary. By definition, to react with an allergy means to react in an immunologically paradoxical way against natural environmental factors.

In 1981, we started a seroepidemiological investigation in the village of Grabs in the upper Swiss Rhine valley, after a boy presented with hay fever. $\mathrm{He}$ wanted to become a baker and his mother asked me what his risk for developing baker's asthma would be. In those days, there were no epidemiologic data regarding the prevalence of allergic sensitization in school kids. Therefore, we started to investigate routinely all pupils who had to come obligatorily for medical school examinations. We did this with the informed consent of their parents (fig. 3) [3]. From these studies, we learned a great deal, especially concerning certain obviously paradoxical phenomena, as are outlined in the following sections of this review.

\section{The Paradox of Dose Effect}

The first analysis of these school kids showed that amongst the children of 80 farmers none were suffering from hay fever. However, it was obvious that these children were exposed to pollen quite extensively. The physicochemical dose-effect principle did not seem to be relevant for the development of a specific sensitization.

This was not a new phenomenon. In 1873, Charles Blackley [4] published his observation that farmers' children suffered less frequently from hay fever. Richard Rehsteiner [5] observed the same when he examined school children in Switzerland in 1926. This phenomenon was largely interpreted as indolence of farmers with regard to this sometimes mild 
Fig. 3. Time trend in the sensitization rate, 1983-2007, of the school children from Grabs at the age of 15 years: RAST/CAP test $>70 \mathrm{kU} / \mathrm{ml}$. The sera of 1986 and 2006 were retested in 2008 with molecular allergens (ISAC test).

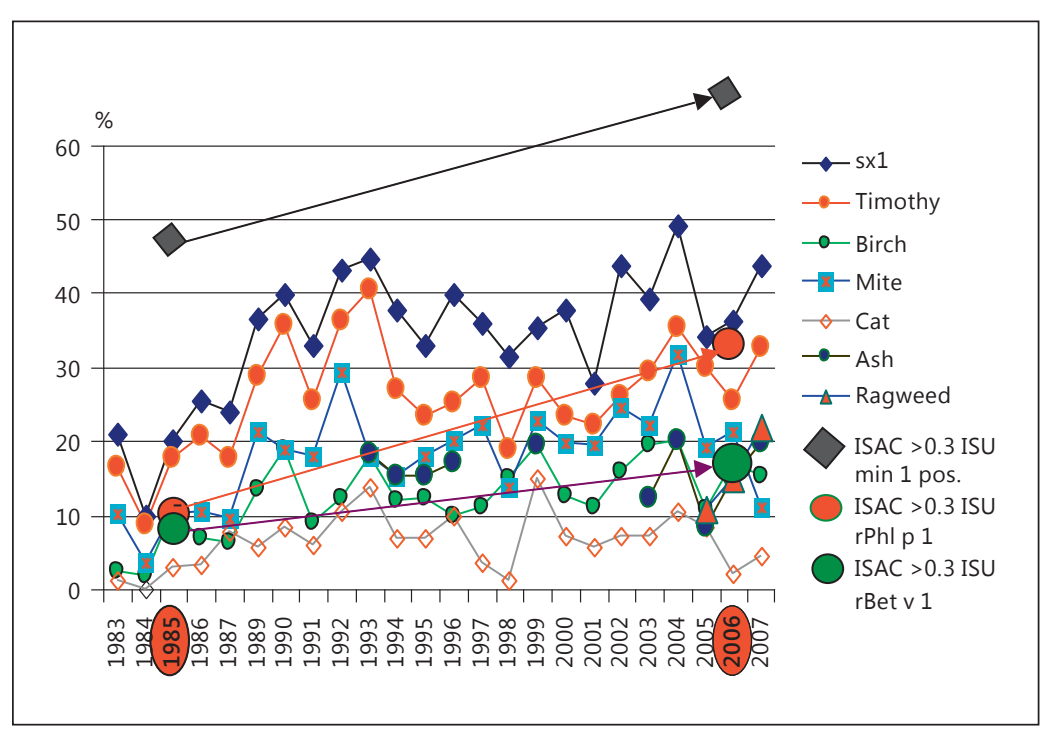

symptomatology, or based on genetic reasons, or it was explained by a healthy worker effect, i.e. those individuals in villages who became allergic would leave the countryside and move to the cities and only the tolerant children would stay and become farmers.

\section{The Paradox of Toxic Interactions}

High sensitization rates against pollen in cities in spite of less exposure led to the idea of an adjuvant effect of pollutants. In Germany, the death of forests ('Waldsterben') was associated with smog in the eastern German states prior to reunification and everybody expected a higher prevalence of hay fever there. However, there was the paradox that East German children had a lower prevalence of hay fever and asthma compared to West German children, as was found in two independent studies by the group led by Erika von Mutius [6] who compared Munich and Leipzig, and the group led by Heidrun Behrendt and Ursula Krämer [7] who compared several regions in West Germany and former East Germany. Also, similar to the studies on farmers' children, the effect was present only in respiratory allergy, while atopic eczema was either equally or more often prevalent among East German children. The East-West difference within Germany or Europe in allergy prevalence cannot be explained only by the farming environment, since classical farmers did not exist in the communist German Democratic Republic. Different patterns of air pollution seem to be of relevance with regard to traffic exhaust emissions, showing an allergy-enhancing effect [8].

Farmers used wood more often, representing their own traditional energy source, for preparing foods and for heating. Their neighbors in Grabs more frequently used a central oil-fired heating and electrical cooking stove.

Considering 'summer smog', farmers' children inhaled more ozone, since they often helped during hay harvesting around noon, the time of high sun and ozone exposure, as well as on a longer walk to school. It can also be considered that at this time children were also hard working, meaning they were forced to ventilate more of all the toxic substances in the air.

\section{The Paradox of Tolerance or Adaption}

Farmers' children show distinct quantitative differences in the sensitization pattern compared to the children of parents not associated with agriculture. Children who only occasionally help on a farm or children of parents who do farming as a part-time job react intermediately. The differences are most significant between farmers' children with regard to specific immunoglobulin (Ig) E levels against timo- 
Fig. 4. Patterns of the quantitative sensitization to timothy grass pollen (CAP g6) according to the paternal profession (farmers) or nationality (migrants) in 1,297 serum samples, 1983-2002. CAP class 1: $0.35-69$, class 2: $0.7-3.49$, class $3: 3.45-$ 17.49 , class $4>5.3 \mathrm{kU} / \mathrm{l} \mathrm{lgE} \mathrm{g6}$.

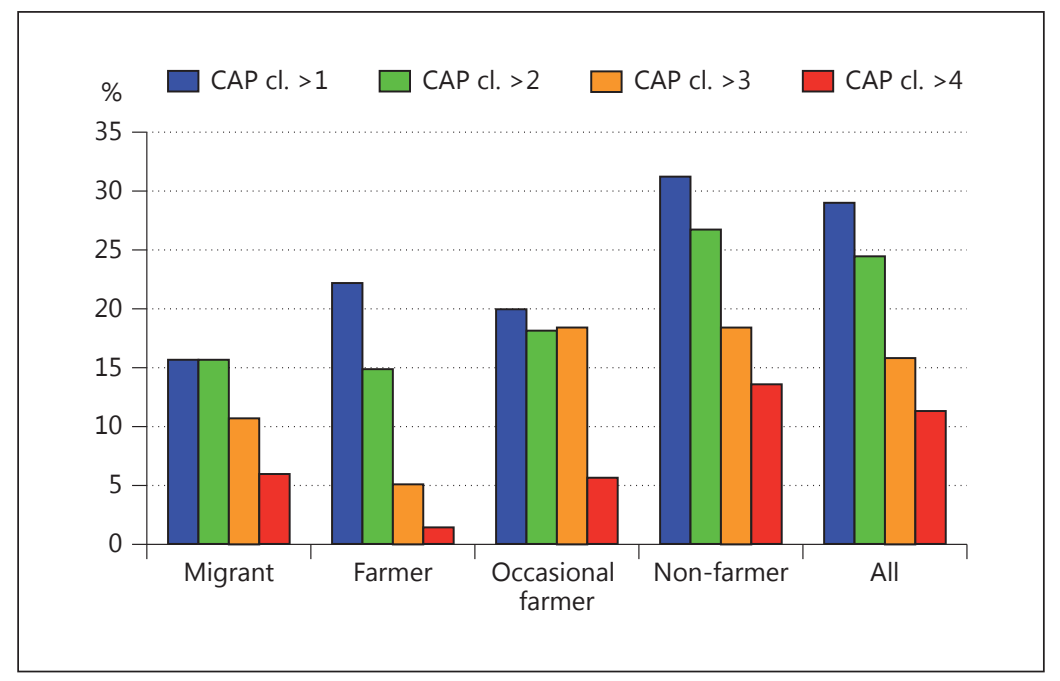

thy grass (Phleum pratense) pollen (fig. 4) [9]. Continuous quantitative and allergen-specific differences argue for adaptation and against tolerance. Adaptation means getting used to a foreign substance by habituation under continuous exposure and can be compared with callus of the skin under chronic irritation or increases in muscle strength by physical training. The term 'tolerance' was coined in 1945 by R.D. Owen [10] when he found that dizygotic twin calves tolerate the blood group of the respective twin. Adaptation should be used for a quantitative and not a permanent reaction to an environmental condition, and tolerance should relate to a clear genetic variation or an acquired cause with a permanent reaction pattern.

\section{The Paradox of Chronic Obstructive Lung \\ Disease}

With fewer allergies and less asthma amongst farmers' children, one might expect lower mortality and morbidity from chronic obstructive lung diseases in their fathers. However, in Switzerland the mortality statistics for the years 1988-1992 in dairy farmers showed the highest and highly significant age-standardized proportional mortality rate (127 for ICD-8 460-519) for all lung diseases, bronchitis and asthma, but not for lung cancer. This phenomenon was not found in farmers who exclusively produce cereals, vegetables or wine [11].

\section{The Paradox of Endotoxins}

In his book written in 1906, Alfred Wolff-Eisner [12], a pioneer of hay fever research, described a lot of aspects related to endotoxins which had been discovered by Richard Pfeiffer in 1904. Analogies to the diphtheria toxin were made; Philipps Dunbar in Hamburg created a serum therapy with 'Pollantin', a horse antipollen serum. The word 'fever', which was also used by Charles Blackley, is older than the discovery of the thermometer. Endotoxins are heatresistant lipopolysaccharides of bacterial cell walls and can cause elevations in body temperature in human beings and mammals. As pyrogenic impurities, they are present in a variety of biological products. While they were difficult to detect some decades ago, when the pyrogen test was only applied in rabbits, it is easier to detect them using the limulus test where endotoxins coagulate the hematolymph of the horseshoe crab (Limulus polyphemus).

A typical feverish disease in dairy farmers is the organic dust toxic syndrome which occurs when mold-contaminated hayricks are emptied and cleaned or when hay is restacked in spring ('Heuschroten'). These well-known reactions in farmers are mostly caused by endotoxins and glucans. Endotoxins can also modify the immune reaction. They possibly stimulate TNF- $\alpha$ production, which might explain antitumor effects with regard to lung cancer, which in turn might explain the lower mortality due 
to lung cancer in farmers [13]. Cigarettes obviously do not play a role here. It is a pity that young smokers lose the irritative intolerance reaction of their bronchi, occurring with their first cigarette! There is no proof that the higher mortality of farmers from COPD is due to smoking. Farmers' children with continuous and/or perinatal exposure to endotoxins show less frequent IgE-mediated sensitizations in epidemiologic studies [14].

\section{The Paradox of Organ Distribution}

Via which organ the primary sensitization occurs remains an open question. Small children usually develop the first sensitization against foods with symptoms of the skin and airways; the most prominent sensitizations are against hen's egg, cow's milk or fish, many of which are lost over time until puberty. Why the sensitization against aeroallergens only occurs later is unclear. Only 30 years ago cross-reactions between pollen and food allergens were discovered; molecular allergology can explain the basis of this first purely clinical phenomenon. Still there is a paradox in explaining the correlations of these infectious diseases. One could expect that common airborne infectious diseases of the airways, such as influenza, respiratory syncytial virus, measles, mumps and rubella, should influence the development of allergic reactions of the lungs like asthma. Matricardi [15], however, showed that the risk is influenced by gastrointestinal infections like hepatitis A, toxoplasmosis and cytomegalovirus.

Helicobacter pylori can obviously cause macroscopically and microscopically visible 'pores' or even ulcera in the gut wall. However, this infection is also more protective with regard to allergies against aeroallergens. In our village of Grabs the seroreactivity of $H$. pylori showed a distinct correlation with the origin of the mother, especially when she came from south-east Europe. This can explain the low prevalence of hay fever in children from migrant populations in spite of a lack of exposure to domestic animals [16].

From these findings one might speculate that the immunity of the airways can be influenced pharmacologically via the gut. Contact with a cow during pregnancy can prevent hay fever at least partially, but keeping a cow is not a good practical recommendation for people living in a city. Therefore, one tries to identify certain germs, especially lactobacilli or other bacteria, with less harmful 'endotoxins'. The first results of clinical trials were scientifically disappointing, although this was not the case commercially speaking, considering the boom of 'healthy' food additives, especially in yoghurt, such as prebiotics and probiotics [17]. The question of which route of application of the allergen might be optimal in allergen-specific immunotherapy remains an open debate today.

\section{The Paradox of Gnotobiotics}

Forty years ago a new strain of mice was discovered which in homozygous animals had no hair (nude mice) and no thymus, and, therefore, no T cell reactivity. These mice had quite a reduced life expectancy even under sterile conditions. When they were living in a gnotobiotic situation, i.e. intestinal flora with harmless germs, they survived much longer. In such a condition they could be better used as hosts for transplanted human cancer cells which could not be rejected, since they had no thymus.

In the human intestinal tract we find a quite diverse biotope of multiple germs which is essential for a variety of functions, such as destruction of animal and plant cell walls, degradation of biochemicals and 'delegated' production of essential substances like vitamins. Many people are quite sensitive to alterations of this intestinal flora, e.g. after the use of antibiotics.

The individual constancy of bacterial colonization is striking. It is generally thought that newborns profit from the enteral environmental experience of their mothers and colonize their sterile neonatal gut during birth with well-known harmless maternal germs. Certain strains of lactobacilli may have a preventive effect in atopic eczema which is short-lasting and does not influence the prevalence of sensitizations in school children. However, there is little epidemiologic information [17], and the pathophysiology is also not well understood. Another relevant question is wherefrom the children born by cesarean section develop their individual gut flora. 


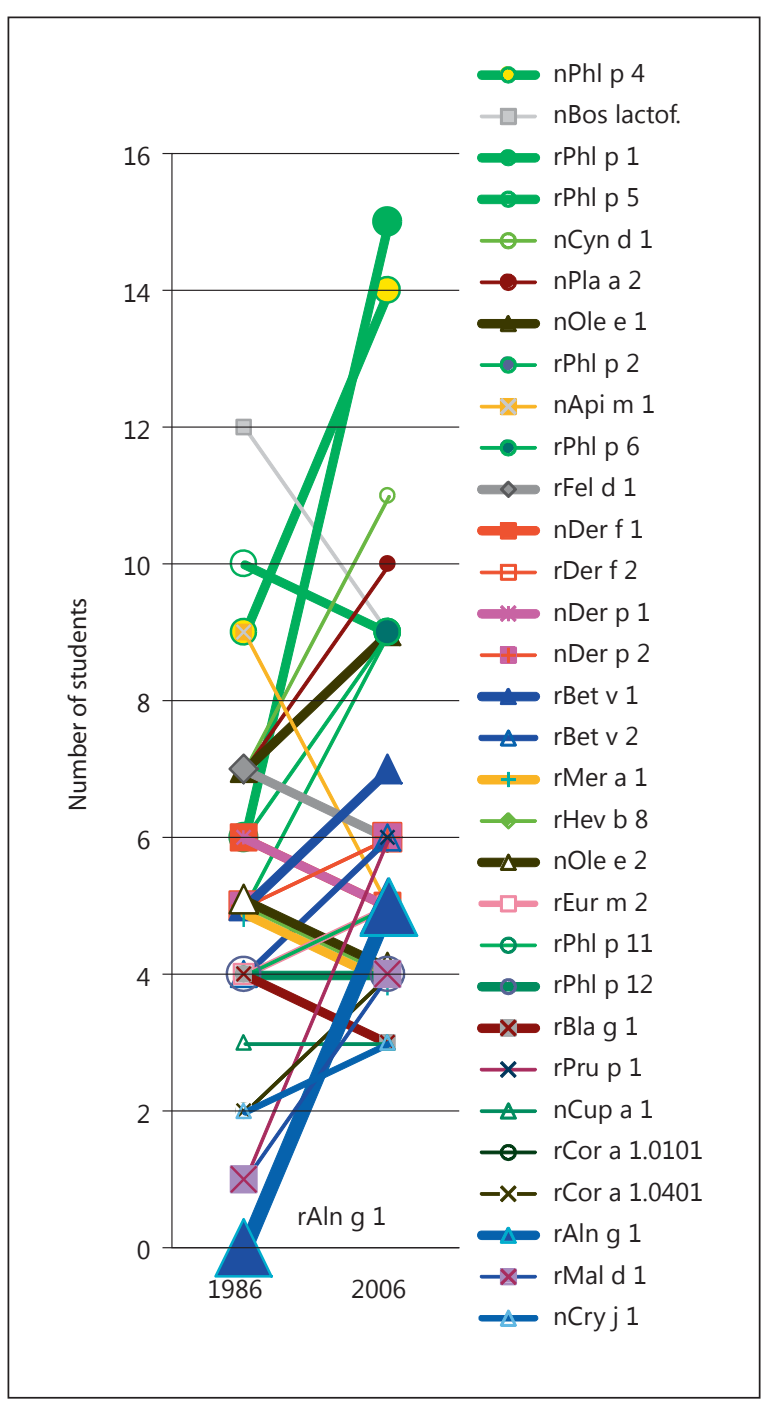

Fig. 5. Changes of IgE seroprevalence ( $>0.3$ ISU) to some molecular antigens in unselected school children of Grabs between 1986 $(n=54)$ and $2006(n=46)$. Particularly striking is the rise of sensitizations to rAln g 1 from 0 to 5 (10.9\%) of the pupils in 2006 .

\section{The Paradox of Genetics}

In human society power is always also dependent upon political genetics. Noble people had to marry within adequate political circles. Equally, the agricultural community preferred the stability of their inhabitants. Heritage laws with regulated consanguinity optimized the long-term richness of generations over generations.
The farmer also depended upon the genetics of his products: which kind of cereal and cattle would yield the most harvest on what area of land? The classical gene technology of ancient times was breeding by selection both in plants and animals. Today, with modern technology, we can introduce heterozygous DNA into animals and plants with all risks and chances. Gene technology is of immense diagnostic help in the epidemiology of microorganisms. The genetic code of a virus gives information about its origin. Monoclonal antibodies allow molecular allergy diagnostics. Farmers' children not only show quantitative differences in sensitizations, but also qualitative specific sensitization patterns against various recombinant allergens.

By molecular analytics new information can be obtained regarding allergen cross-linking. The school children investigated in 2006 in Grabs showed much higher sensitization rates against rAln $\mathrm{g} 1$ than those from the year 1986 (fig. 5). Looking at regional sources we found that 15 years ago a main street was newly planted with alders. These alders (Alnus spaethii) probably originated from Kew (London) in 1894 and were cultivated in Berlin. They were first described by Callier in 1908 as a hybrid of A. japonica and A. subcordata [18]. Without a natural habitat they seem to be man-made, created through crosspollination. It was clearly a voluntary outdoor experiment conducted by man by planting a genetically altered large organism. The tree looks beautiful, but is already pollinating in December! Its PR-10 protein shows a different homology to $\mathrm{rBet} \mathrm{v} 1$, otherwise it would not have been detected in this epidemiological study. Will this imported tree propagate Japanese or Caucasian genes among the domestic alders?

\section{The Paradox of Migration}

Migrants do not change their genes, but rather their environment. Consequently, they represent a film negative of the farmers' 'stabilitas loci'. They do not breed animals, and even tend not to keep pets, because kept animals impede mobility. Their spectrum of sensitization reflects partly their origin and partly the actual interaction with their new environment.

As for allergies, it is interesting that children from migrants react quantitatively in a similar way to 
farmers' children in the northern Alps (fig. 4). They are also quantitatively less frequently sensitized towards aeroallergens.

\section{The Paradox of Slums}

All the paradoxes mentioned show that the socalled hygiene hypothesis can only explain partial aspects of the 'allergy' phenomenon. Dirt is not healthy, even if traditional lifestyle in Europe can have protective advantages regarding the development of allergies. Children in marginal countries of the world, especially in slums, show quite different reaction patterns in their IgE systems; they react less frequently to various pollen, but more often to aeroallergens of animal origin, especially mites.
The internet has changed our attitude towards books and libraries, yet the knowledge of a single individual is still rather limited. Our immune system can be compared to the nervous system not only in weight, but also in its interaction with the environment, its talent for specificity and its remarkably good memory. Our brain is only able to recognize a certain relation, either as images, like the eye of an insect, or like a mirror and in fragments. Let us hope that these short reflections on historical developments regarding the influences of the farming environment may have beneficial effects for our children with regard to preventive strategies and risk avoidance.

\section{References}

1 Ackermann JC-G: Bernhard Ramazzinis (1633-1714) Abhandlungen von den Künstlern und Handwerkern. Stendal, Franzen und Grosse, 1780.

2 Steiner W: Untersuchungen über die Konservierung von Grünfutter nach dem Verfahren von A.I. Virtanen; Dissertation. Zürich, Leemann \& Co., 1936.

3 Gassner M: Häufigkeit allergologischer Erkrankungen bei Schulkindern einer Landbevölkerung im Hinblick auf die Berufsberatung. Zbl Haut Geschlechtskrankheiten 1985;150:649.

4 Blackley C: Experimental Researches on the Causes and Nature of Catarrhus Aestivus (Hay Fever or Hay Asthma). London, Ballière, Tindal and Cox, 1873 (facsimile: Abington, Oxford Historical Books, 1988, pp 155-156).

5 Rehsteiner R: Beiträge zur Kenntnis der Verbreitung des Heufiebers; Dissertation. Zürich, Hans Gutzwiller, 1926.

6 von Mutius E, Weiland SK, Fritsch C, Duhme H, Keil U: Increasing prevalence of hay fever and atopy among children in Leipzig, East Germany. Lancet 1998;351: 862-866.
7 Krämer U, Behrendt H, Dolgner R, Ranft U, Ring J, Willer H, Schlipköter HN: Airway diseases and allergies in East and West German children during the first 5 years after reunification: time trends and the impact of sulphur dioxide and total suspended particles. Int J Epidermiol 1999;28:865-873.

8 Behrendt H, Becker WM: Localization, release and bioavailability of pollen allergens: the influence of environmental factors. Curr Opin Immunol 2001;13:709-715.

9 Braun-Fahrländer C, Gassner M, Grize L, Neu U, Sennhauser FH, Varonier HS, Vuille JC, Wüthrich B, SCARPOL Team: Prevalence of hay fever and allergic sensitization in farmer's children and their peers living in the same rural community. Clin Exp Allergy 1999;29:28-34.

10 Owen RD: Immunogenic consequence of vascular anastomosis between bovine twins. Science 1945;102:400.

11 Gassner M, Spuhler T: Warum sterben Bauern häufiger an Lungenkrankheiten? Schweiz Med Wochenschr 1995;125:667675.
12 Wolff-Eisner A: Das Heufieber, sein Wesen und seine Behandlung. München, Lehmanns, 1906, pp 130-131.

13 Rylander R, Peterson Y: Organic dusts and lung disease. Am J Int Med 1990;17:1-148.

14 von Mutius E, Braun-Fahrländer C, Schierl R, Riedler J, Erlenmann S, Maisch S, Waser M, Nowak D: Exposure to endotoxin or other bacterial components might protect against the development of allergy. Clin Exp Allergy 2000;30:1230-1234.

15 Matricardi PM, Rosmini F, Ferrigno L, Nisini R, Rapicetta M, Chionne P, Stroffolini T, Pasquini P, D’Amelio R: Cross sectional retrospective study of prevalence of atopy among Italian military students with antibodies against hepatitis A virus. BMJ 1977; 314:999-1003.

16 Heuberger F, Pantoflickova D, Gassner M, Oneta C, Grehn M, Blum A, Dorta G: Helicobacter pylori infection in Swiss adolescents: prevalence and risk factors. Eur J Gastroenterol Hepatol 2003;15:179-183.

17 Bischoff S (ed): Probiotica, Präbiotica und Symbiotica. Stuttgart, Georg Thieme, 2009.

18 Callier AS: Neue Gehölze: Alnus spaethii. Mitteil Deutsch Dendrol Ges 1908:215-216.

\title{
(C) Free Author Copy - for personal use only
}

ANY DISTRIBUTION OF THIS ARTICLE WITHOUT WRITTEN CONSENT FROM S. KARGER AG, BASEL IS A VIOLATION OF THE COPYRIGHT.

Written permission to distribute the PDF will be granted against payment of a permission fee, which is based on the number of accesses required. Please contact permission@karger.ch

\author{
Dr. med. Markus Gassner \\ General Practitioner and School Physician \\ CH-9472 Grabs (Switzerland)
}

E-Mailm.gassner@hin.ch 